\title{
Health Expenditure and GDP Growth in Botswana
}

\author{
Narain Sinha* \\ Professor of Economics, University of Botswana, Gaborone, Botswana
}

\begin{abstract}
Botswana has always been recognised as an economically stable and upper middle income country in SubSahara Africa, very often celebrated as a model economy for its prudential fiscal management. In 2009 Botswana become one of the few countries which have met the Abuja targets in per capita health expenditure. Amidst a high literacy rate and reasonably high economic growth, health expenditure being the highest among the SADC countries, Botswana has the HIV/AIDS prevalence which is one of the highest in the African continent. A stable relationship between health expenditure growth and income growth is crucial for health policy formulation. Four issues associated with health expenditure in the estimation of income elasticity which have not been adequately addressed in earlier studies are role of technology, heterogeneity of the health expenditure, treatment of structural break and dynamic aspects of health expenditure. This paper attempts to address these issues while estimating the income elasticity of health expenditure for Botswana considering both macro-data for 1981-2016, and micro-data drawn from the Household Income Expenditures Surveys, 1993/94 and 2003/04 according to residence status. Our results for Botswana indicate that the health care is a necessity at least in the short run. This is in contrast to the available evidence for other countries especially among upper middle income and in Africa.
\end{abstract}

Keywords: Autoregressive Distributed Lag, Gross Domestic Product (GDP), Health Expenditure, Income Elasticity JEL Classification: C31, C5; C51; C52, H51, H73, I18, I38, I51

\section{Introduction}

Expenditure on health is an important factor influencing the health outcome of a country. During the first decade of the $21^{\text {st }}$ century when most of the economies were growing their health outcomes were not improving proportionately, particularly among the African economies. Acknowledging the poor performance of health indicators and the key role played by public funding to ensure sustainable and equitable health coverage, the African Union heads of state in 2001 pledged to allocate at least $15 \%$ of annual expenditure to health under the Abuja Declaration considered as an important first step in the Millennium Development Goals (MDG) era and remains a unique initiative in the history of financing health and social goals. Fifteen years later, most African governments have increased the share of total public expenditure allocated to health. In addition, the average level of per capita public spending on health increased from about US\$70 in the early 2000s to more than US\$160 in 2014 (at PPP). Health sector in Africa is predominantly financed by domestic resources (WHO, 2016) (Table 1).

Relationship between health expenditure (here after $\mathrm{HE}$ ) and income has been discussed for several reasons which include inter alia examining the response of change in gross domestic product (here after Gross Domestic Product (GDP)) to the HE, determinants 
of $\mathrm{HE}$, etc. Response of change in income to $\mathrm{HE}$ is measured in terms of what is known as income elasticity of expenditure on health and its magnitude is crucial policy parameter. If it is more than unity then $\mathrm{HE}$ is regarded as a luxury and if it is below unity then it is treated as necessity. Whether healthcare spending tends toward luxury good or necessary good has been debated in several studies considering both intra- and inter-country data. Similar studies based on more recent data and relevant for macroeconomic health policies for an individual country especially an African country are scant. Response of change in GDP on the health care expenditure in Africa relevant for health policy is important because of lower health outcome and health care is a necessity in the 'basic needs'.

Plan of the paper is structured as follows: Section 2 presents the trend and composition of health expenditure in Botswana followed by a review of literature in section 3. Methodology is given in Section 4 and econometric evaluation of the estimation within the framework is presented in Section 5. Finally, the summary is given in Section 6 .

\section{Health Expenditure in Botswana}

A politically stable country in Southern Africa Botswana has always been recognised as a fast growing middle income economy going through a dramatic situation with regard to HIV/AIDS infection: sero-prevalence rates that are HIV positive is among the highest in the world with more than $37 \%$ of adult population (15 to 49 years) in 2003 (WHO, 2005). The country has one of the highest rates of spending on health among the Southern Africa Development Community (SADC) countries and countries of the World Health Organisation (WHO) Africa region (Lule \& Haacker, 2012). The Abuja declaration came as a solution to problem of financing health expenditure by setting targets for African countries; to invest at least $15 \%$ of government budget on health and to have less than $20 \%$ of the total health expenditure coming from out of pocket spending. Botswana is one of the few countries in Africa which met the Abuja target on health in 2009 and hence can boast of meeting both these targets (WHO, 2013). This is a great achievement for Botswana commended for its commitment to allocating more resources to health. Health care in Botswana is delivered through a decentralized system with primary healthcare being the pillar of the delivery system. There is a consistent growth in GDP and in government expenditure on health in Botswana during 1981-2016 (Figure 1). In terms of GDP, government spending on health, it is also well above the average of the SADC region of 4.8 per cent (Republic of Botswana, 2012). Surprisingly, some of the interesting characteristics about the health sector have not been researched for Botswana. The aim of our study is precisely to fill this gap by associating the national health policy and its fiscal implications. Trends in total government expenditure and its components are shown in (Figure 1).

The secular trend in total expenditure on health during 1981-2016 is mainly due to a large share of Recurring Health Expenditure (RHE) consisting of rising wages and incomes which constitutes a major factor. On the other hand the Development Health Expenditure

Table 1. Level of attainment of Abuja targets in Africa

\begin{tabular}{|l|l|l|}
\hline & $\begin{array}{l}\text { GGHE/GGE more } \\
\text { than 15\% }\end{array}$ & GGHE/GGE less than 15\% \\
\hline $\begin{array}{l}\text { Total health expenditure per capita } \\
\text { more than US\$ } 44\end{array}$ & $\begin{array}{l}\text { Botswana, Rwanda, } \\
\text { Zambia (3 countries) }\end{array}$ & $\begin{array}{l}\text { Algeria, Angola, Cameroon, Cape Verde, Congo, Côte d'Ivoire, Equatorial Guinea, Gabon, Ghana, } \\
\text { Guinea-Bissau, Lesotho, Mauritius, Namibia, Nigeria, Sao Tome and Principe, Senegal, Seychelles, } \\
\text { South Africa, Swaziland, Uganda (20 countries) }\end{array}$ \\
\hline $\begin{array}{l}\text { Total health expenditure per capita } \\
\text { less than US\$ 44 }\end{array}$ & $\begin{array}{l}\text { Madagascar, Togo } \\
\text { (2 countries) }\end{array}$ & $\begin{array}{l}\text { Benin, Burkina Faso, Burundi, Central African Republic, Chad, Comoros, DRC, Eritrea, Ethiopia, } \\
\text { Gambia, Guinea, Kenya, Liberia, Malawi, Mali, Mauritania, Mozambique, Niger, Sierra Leone, } \\
\text { Tanzania (20 countries) }\end{array}$ \\
\hline $\begin{array}{l}\text { GGE General government } \\
\text { expenditure, GGHE General } \\
\text { government health expenditure }\end{array}$ & & \\
\hline
\end{tabular}

Source: Reproduced from Piabuo and Tieguhong (2017). 


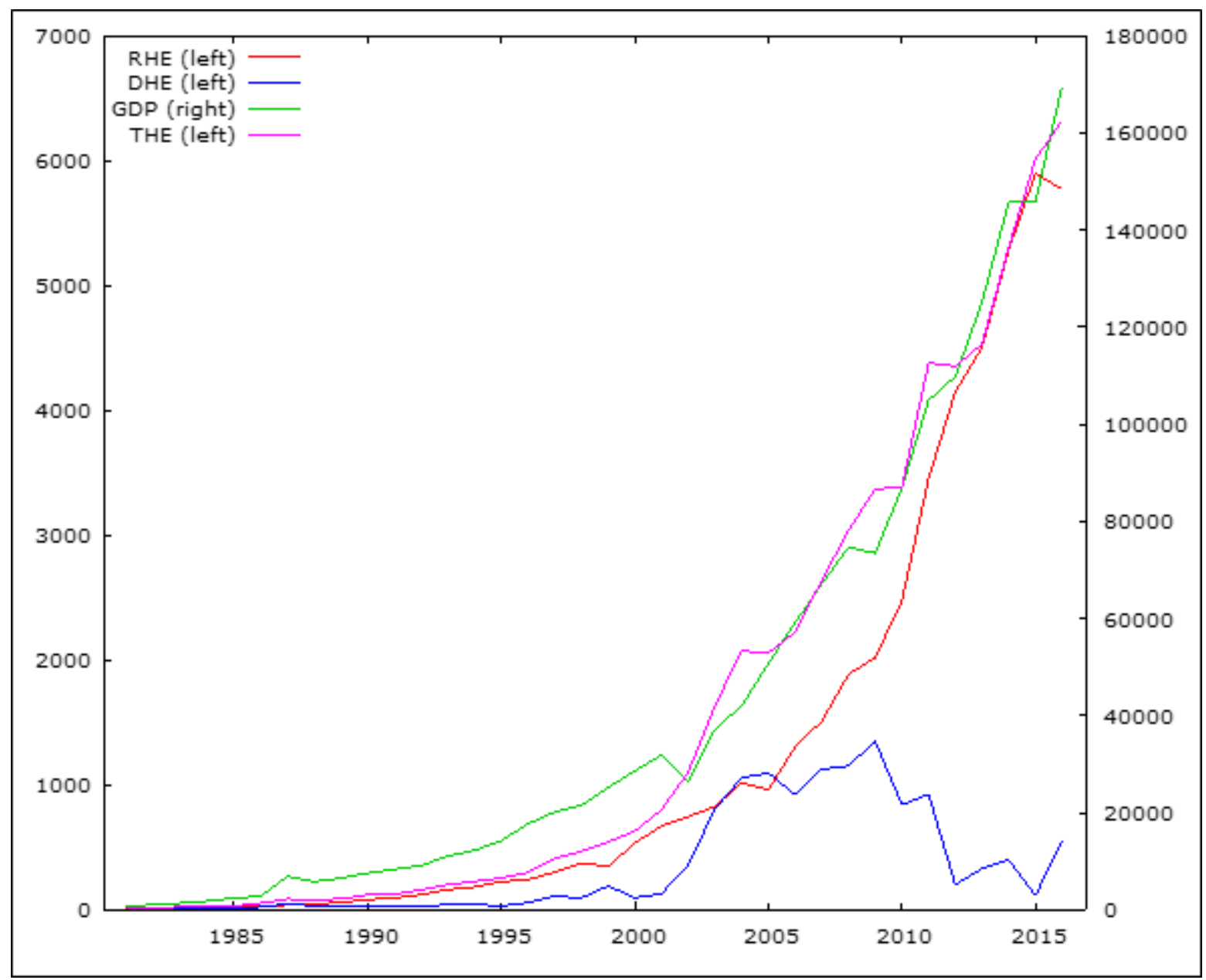

Figure 1. Trend in total health expenditure, recurring health expenditure, development health expenditure, and GDP current price (in million Pula) 1981-2016.

(DHE) which had moderate growth in the initial period started plummeting after 2005. Indeed in Botswana, much of the growth in health spending has taken place due to RHE particularly after the year 2002 when MASA programme was introduced and the growth in total public expenditure has come from this technical change ${ }^{-}$. In Botswana new medical technologies can be considered in terms of ART which has created demand

\footnotetext{
${ }^{1}$ National AIDS Coordinating Agency (NACA) in Botswana worked on a comprehensive strategy for HIV/ AIDS treatment under which the government decided to make Anti-Retroviral Therapy (ART) widely available as a central component of the strategy, Merck agreed to donate the drugs free of charge. In 2002, Botswana was ready to adopt this ambitious program christened it Masa, meaning "New Dawn" in Setswana.
}

and led to increase in public expenditure particularly RHE.

Over the period, a larger part of government expenditures goes into improved medical technology such as equipment, medicines, surgical techniques, etc. Such technological improvements that emerge over time alter the pattern and amounts of medical care demanded.

The HIV prevalence rate in Botswana is one of the highestin the African continent. First case of HIV was detected in Botswana in the year 1983 but the public health programmes directed at HIV/AIDS have been in place since 1987. Until the year 2001 the government expenditure on health was under $2 \%$, but after the 
introduction of Anti-Retroviral Therapy (ART) programme in 2002 it increased to about $4 \%$ and this has severe financial implications (Lule \& Haacker, 2012). It should be noted that during 2003-2013 the national prevalence rate has gone up from 17.1 to 18.5 per cent. During this period, recurring expenditure went up from $68 \%$ to $93 \%$ of the total health expenditure (Table 2 ).

The national prevalence rate for age group of 18 months to 64 years was estimated at 19.03 in 2013 as per the BAIS IV survey is high as compared to 17.6 percent in the BAIS III survey $\stackrel{2}{2}$ in 2008 for the same group. The national prevalence rate in Botswana was 17.1 per cent in 2003 which increased marginally to 17.6 in 2008. It has gone up again to 18.5 in 2013 (CSO, 2004). In the year 2002, the national antiretroviral (ARV) treatment programme termed as MASA, first programme to provide ARV treatment nationwide at no cost through public sector in Sub-Saharan Africa, was launched in Botswana which has severe fiscal implications (Lule

${ }^{2}$ Botswana Aids Impact Survey (BAIS) I was conducted in 2001 thereafter BAIS II, BAIS III and BAIS IV were conducted in 2004, 2008 and 2013, respectively.
\& Haacker, 2012). As stated earlier, the first case of HIV in Botswana was observed in 1983 and the ARV programme was introduced in 2002.

Growth in the government expenditure during 19812016 was very modest; but because of a number of changes introduced in the health system in Botswana during the last decade such as the adoption of user fees exemptions for the elderly and other vulnerable groups, introduction of MASA in 2002, and increased donor support have resulted in a sharp increase in the total health expenditure and also recurring health expenditure. The share of government expenditure in GDP was almost under $2 \%$ until the year 2001, however thereafter it started increasing during the last decade as shown in (Figure 2). Later the share of total government expenditure (THESH) on health has declined from $4.29 \%$ of GDP in 2002 to $3.88 \%$ in 2016 .

\section{Health Expenditure and Income}

Over the last decades, health expenditure has increased globally with the economic growth. Grossman (1972)

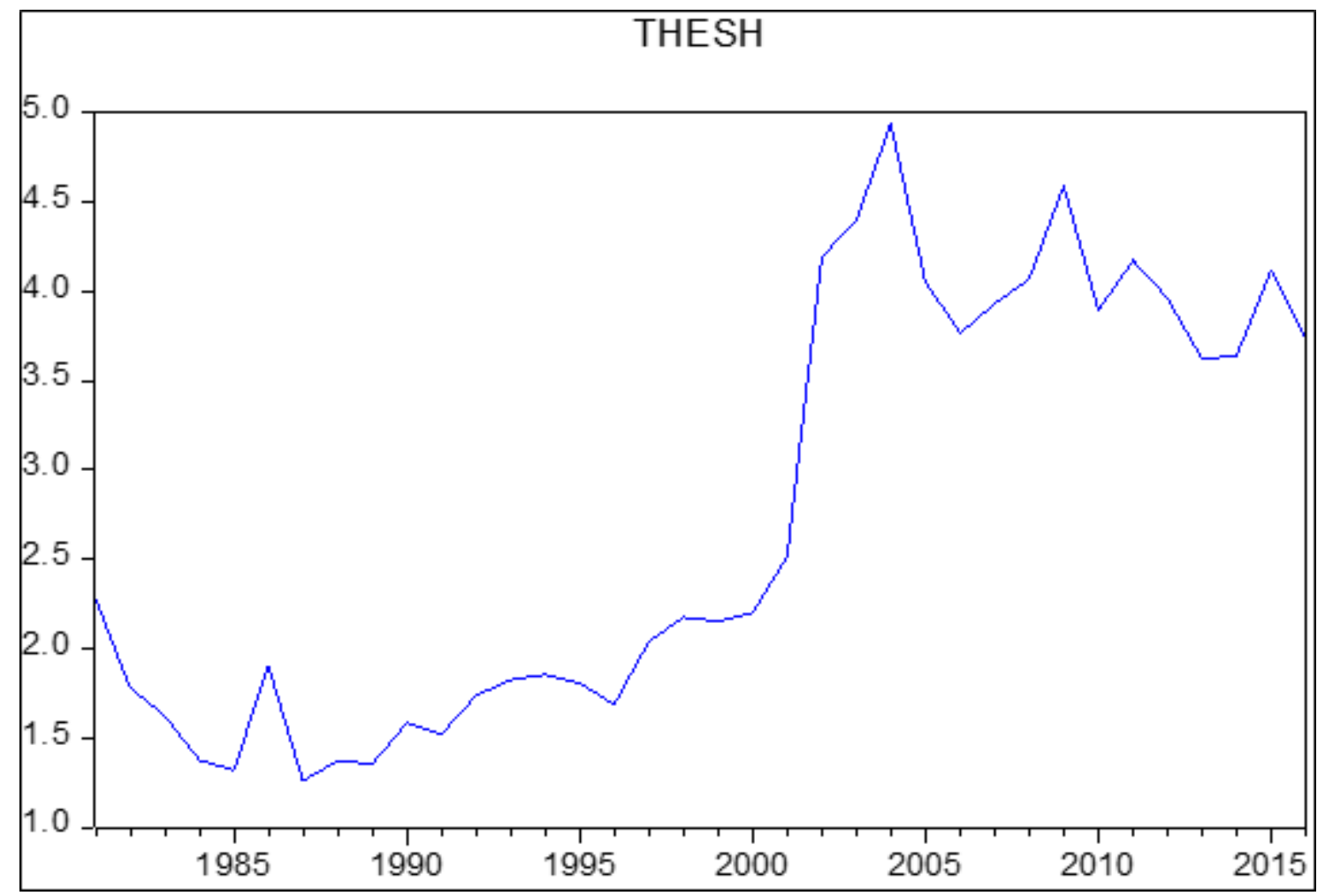

Figure 2. Share of Government Total Health Expenditure (THE) in GDP, 1981-2016. 
Table 2. HIV prevalence rate among adults, share of health expenditure and GDP in Botswana

\begin{tabular}{|c|c|c|c|c|}
\hline & 2001 & 2005 & 2009 & 2013 \\
\hline & BAIS-I & BAIS-II & BAIS-III & BAIS-IV \\
\hline $\begin{array}{l}\text { Prevalence Rate } \\
15-49 \text { years }\end{array}$ & 27.70 & 25.40 & 23.60 & 21.90 \\
\hline \multicolumn{3}{|l|}{$\begin{array}{l}\text { THE/GDP } \\
2.52 \\
4.05\end{array}$} & 4.66 & 3.65 \\
\hline RHE/THE & 83.85 & 46.67 & 59.94 & 99.51 \\
\hline DHE/THE & 16.15 & 53.34 & 40.06 & 7.29 \\
\hline $\begin{array}{l}\text { THE/GOVT } \\
\text { Expenditure }\end{array}$ & 5.87 & 11.66 & 8.54 & 1.08 \\
\hline GDP (in Million Pula) & 31922.00 & 50752.00 & 72316.00 & 124223.00 \\
\hline
\end{tabular}

Source: Various Issues of BAIS and Annual Reports of Bank of Botswana, Gaborone

considers income and quality of medical care as two important factors that influence health expenditure. Relationship between expenditure on health as demand for health and income was first conceived in Kleimann (1974) and later by Newhouse (1977) employing a simple linear model and estimated income elasticity of health expenditure above unity. Income elasticity is influenced by quality of health care through accessibility, affordability, availability and epidemiology of the country and its magnitude may indicate whether the health care is above or below unity (Sulku \& Caner, 2011). If its magnitude is positive and its value is low, i.e. its response is small, indicating that the health care is a normal good. If income elasticity is positive and its value is below unity then the good is a necessity and the government has to make provision for health care. In case if its value is positive and exceeds unity then health may be regarded as luxury and may be left for the private sector. If it is negative then health is regarded as an inferior good. At the micro level the magnitudes of income elasticity are small suggesting that the health is necessity. However, at micro level small magnitude is obtained suggesting that the health is a necessity. Normally; in poor societies the demand for medical care is higher because of poor living conditions. The theoretical link between per capita GDP and HCE is depicted in (Figure 3).

The empirical evidence on income elasticity of health expenditure suggests that its value increases if the

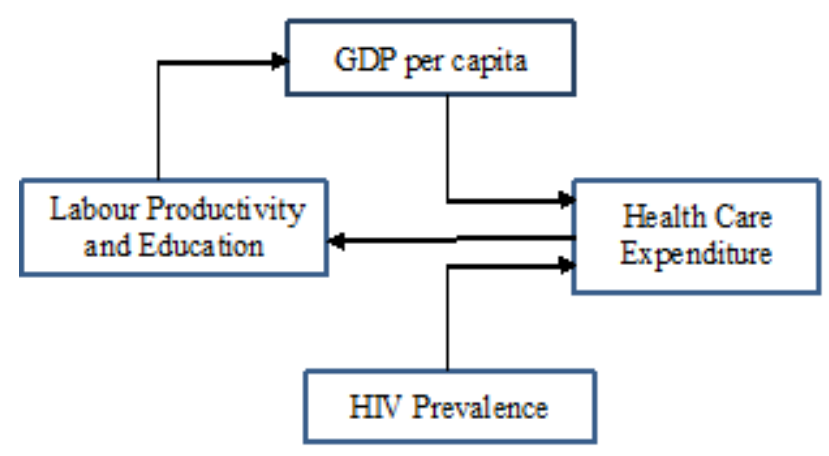

Figure 3. Causal relationship between HCE and economic growth.

Source: Adapted by author from Khan, et al. (2016)

statistical units considered in the investigation shifts from micro (e.g. individuals, provinces, regions) to macro (e.g. States and Countries) level (Moscone \& Tosetti, 2010). Getzen (2000) argues that health care is a luxury good at the aggregate level, but at the individual level it is a necessity. Consequently, there is no agreement in the literature on the magnitude of income elasticity based on the relationship between expenditure on health and income. Most of the existing literature focuses mainly on developed countries particularly the OECD and industrialized countries. Wide variations in the magnitude of income elasticity in previous literature are observed and may be attributed to the problem associated with the aggregation of units of observations, aggregation of total expenditure and specification problem'. On the one hand at the aggregate level, using panel data from industrialized or OECD countries obtain the income elasticity greater than unity (Culyer, 1988; Parkin, et al., 1987; Gerdtham \& Jonsson, 1991; Okunade \& Murthy, 2002; Gerdtham, et al., 1992). By separating public health expenditure from private health expenditure it is possible to address some of these issues relating to heterogeneity because of heterogeneous pattern implicit in both these types of expenditure which are significantly different (Clemente, et al., 2004). Further, one would expect health care to be less dependent on the ability to pay at the micro level in those countries where health care is heavily subsidized. However, at the macro level, health care depends more on accessibility and not so much on affordability when income is growing particularly in the initial stage of development. 
The main question raised in earlier studies about the nature of healthcare expenditure is whether its elasticity is greater or less than unity that is if it is the luxury or necessary. The controversy over the magnitude of the income elasticity of health care has been exacerbated by its policy implications. If the income elasticity is smaller than one the health care is a necessity and policy maker recommend greater public involvement in health care. Conversely, if the income elasticity is more than one then the health care considered as a luxury and policy maker would argue it be treated as a commodity much like any other and be best left to market forces alone (Culyer, 1989). In the literature on the relationship between health expenditure and income the basic objective has been to asses if the income elasticity is above or below unity. Studies on estimation of income elasticity may be put in two categories. First, there are macro level studies which have used aggregate data on a single country and on cross-country data at one point of time or over a period of time. Besides, there are studies based on panel of countries such as OECD, Asian, EU and African. Heterogeneity across the countries in the panel data is the major limitation. Finally, there are some studies which are based on primary data at micro level for health expenditure a whole or for expenditure on some specific disease. Empirical evidence varies drastically according to the units of observation as a single country or panel of countries considered in the investigation (Blomquist \& Carter, 1997; Getzen, 2000). As the focus shifts from fine disaggregation of the population (e.g. individuals, provinces, regions) to larger groups of actors (e.g. states and countries), a higher estimated income elasticity of health care is observed (Moscone \& Tosetti, 2010).

A summary of previous studies is given in Appendix. For developed countries, the estimates of income elasticity was found ranging from 1.15 to 1.31 when medical expenditure was regressed on income both per capita and concluded that despite within-country results showing health care to be necessity; in fact it is a luxury at the aggregate level (Newhouse, 1977). Updating Newhouse's works with a renewed emphasis on exogenous changes in technology and the growth in aggregate income as the primary determinants of rising health care expenditures Smith, et al. (2009) supported the result. Considering various sub-groups of countries such as developing and low income areas of the world, besides a global perspective, Baltagi and Moscone (2010) obtained the elasticity estimates which vary greatly depending on the sub-sample analyzed seem to suggest that size of income elasticity depends on the position of different countries in the global income distribution, with poorer countries showing higher elasticity. Most of the earlier studies have considered the aggregate health expenditure and GDP relationship. Analysis of disaggregation of total health expenditure is particularly crucial for two reasons. Firstly, it is likely the subcomponents which are subject to individual policies and reforms behave differently from the aggregate health expenditure. Supporting the same argument various studies (Gerdtham, et al., 1992; Goodman, 2000; Getzen, 2000) conclude that the response to more income at micro level is different from that at macro level. The argument is that symptoms of illness and pain are often more important factor for an individual, whereas available health care resources and technologies are important at the macro level for the nation as a whole (Pratt, 2015). Secondly, governments face different incentives for allocating funds to various areas of health care which may alter the long-run relationship between national income and the subcomponents of health expenditure (Sharma \& Srivastava, 2011; Leu, 1986).

During last four decades several attempts have been made to estimate income elasticity of health expenditure. At macro level, using the data for industrialized countries and OECD countries, Schieber (1992) and Narayan, et al. (2011) respectively estimated the linear model and obtained the income elasticity greater than unity. Although nothing significant emerged from such cross-country regressions, it depends more on the stage of development. Notwithstanding several weaknesses in the panel data, Parkin, et al., (1987) offered improved results supporting the luxury good argument. On the contrary for similar data set some studies estimated the income elasticity lower than the unity (Sen, 2005; Dregen \& Reimers, 2005; Chakroun, 2010; Baltagi \& Moscone, 2010). Considering panel data on developed countries over time, Blomquist 
and Carter (1997) observed that in case of majority of the countries the null hypothesis of income elasticity equal to unity could not be rejected. Similar result was obtained by Narayan, et al., (2011) for some countries among OECD. Again using a panel data set for the states in the US, Freeman (2003) and Moscone and Tosetti (2010) estimate the income elasticity of health care to be well below unity, confirming that health care expenditure is a necessity, but when the assumption that endogenous technology advance mostly decided by GDP is considered Woodward and Wang (2012) estimated the income elasticity of health expenditure for states in the US economy above unity.

Considering per-capita health expenditure for crosssection of African countries, Okunade (2005) and Jaunky and Khadaroo (2008) observed the income elasticity below unity signaling the tendency for health care to behave like a 'necessity'. Murthy and Okunade (2009) suggest that health care in the African context is technically a necessity rather than a luxury good (as it is for the OECD countries). On the contrary, there are wide ranges of studies that have generated income elasticity of medical care larger than unity concluding that medical care is a superior good (Baltagi \& Moscone, 2010; Boungarasy, 2011; Carrion-i-Silvestre, 2005). Using data on 167 countries over the period 1995-2012, collected from the World Bank data set, Baltagi and Moscone (2010) estimated the long-run economic relationship between healthcare expenditure and income in the world using panel data methods suggest that at the global level, health care is a necessity rather than a luxury. Thus, the size of income elasticity varies greatly depending on the sub-sample considered, with poorer countries (showing higher elasticity). Cross-country approach most authors have adopted, but on the ground of heterogeneity some authors have ruled out this approach (Saez \& Murillo, 1994; Murillo, Piatecki, \& Saez, 1993).

The aggregate time series estimator for a single country has been scant. There are a few studies for Iran (Rezaei, et al., 2016), Turkey (Kiymaz, et al., 2006), and Jordan ((Istaiteyeh \& Ismail, 2017). Wide variation in the size of the estimates of the income elasticity of health expenditure may be attributed to the sensitivity to the specification of the model employed for the estimation of income elasticity (Roberts, 1999). It is observed that wide variation in the size of the income elasticity may be due to the fact that most of the studies have not considered heterogeneity of health expenditure and specification error which may include role of technology in the growth of health expenditure, dynamic nature of health expenditure and the effect of structural break .In the present study considering the time series for a vibrant economy of Botswana an attempt is made to consider these aspects while estimating the income elasticity of health expenditure. Attention is mainly paid to the contemporaneous effect of GDP on the health expenditure by estimating short run and ling run income elasticity of health expenditure. We have attempted to incorporate the dynamic nature of the health care spending (Lago-Penas, et al., 2013).

\section{Methodology and Data Sources}

The health expenditure in a country is driven by demand-side factors, such as ageing and the health status of a population, income growth, and consumer behavior, and the supply-side factors, such as technological progress and changes in treatment practices, productivity, and health prices which may include the cost of transportation; and regulatory factors, such as institutional characteristics of health systems and their financing. In case of many African economies, financing includes funding from international agencies. As in most of the countries, public expenditure on health has increased in African economies in general and in Botswana in particular. An increase in expenditure on health sector in the economy has not been investigated as extensively as has been done for developed countries where the increase in health expenditure has led to increase in quality or quantity of the health facilities. The quality of medical care is a luxury in case of upper and middle income economies. On the other hand, in the countries with lower income there is sufficient scope for increase in expenditures on health care which is more a necessity. In these countries poor medical facilities may yield the income elasticity generally higher than unity, but the reason is not the same usually given for developed countries. 
Similar conclusions are obtained when primary data are used at micro level when the estimation of the elasticity is lower than unity. Expenditure on health care is commonly regarded as a necessity. On the contrary, several studies of aggregate health expenditures across the countries report substantially higher estimates of income elasticity and often the magnitude exceeding unity. The dependent variables in these studies were either total expenditures on health care or the expenditures for hospital and physician services. In some cases however, physicians visit per capita, physician office visit, surgical services, hospital admission per capita, hospital length of stay, nursing home residents per elderly population, or nursing home patient days per capita elderly was taken. Getzen (2000) has provided a theoretical argument for the discrepancy in the value of income elasticity as estimated at macro and micro level.

\subsection{Empirical Results}

The health expenditure by government and private households has different patterns of behavior depending upon the location. This led to consider public expenditure and private expenditure separately. It may characterize health as a necessary good as far as private expenditure is concerned and a luxury good for government expenditure. For private expenditure on health care and income we consider data from the Household Income and Expenditure Surveys (HIES) conducted for three years 1985/86, 1993/94 and 2002/03 (CSO, 2004). Using the data for the two years, the arc-elasticity (Phelps, 2003) for private expenditure on health care with respect to disposable income has been computed by regions, viz., urban, urban-village, and rural and the results are given below in (Table 3). Magnitude of income elasticity supports our view that in rural areas it is high because of poor accessibility of health care. The patterns of the income elasticity of demand for medical correspond to intuition about the medical "necessity". Income elasticity is smaller in urban areas as compared to rural areas in Botswana as has been the case in Ghana and Sudan. This is because the medical spending is more responsive in rural areas than in urban areas. The highest response in urbanvillage areas is because the period 1993-94 to 2002-03 witnessed more expansion of medical facility in these areas in Botswana as is evident from a sharp increase in development expenditure during this period as is evident from (Figure 1) (Sinha \& Onyatseng, 2013).

At the aggregate level, the income elasticity is positive but less than unity (0.3011) in Botswana similar to Tanzania. Thus, from this, it can be concluded that medical expenditure is not a luxury or superior commodity in Botswana if micro data are considered. Similar result is obtained in earlier studies undertaken for the developed countries. The health expenditure rise faster with incomes in urban than in rural areas in Kenya and Tanzania (Okunade, 1985). However, our results for Botswana do not support this conjecture, because the elasticity is the least in urban areas in comparison to Ghana, Malawi and Sudan.

\subsection{Modeling Health Expenditure}

Four issues associated with the estimation of income elasticity of health expenditure scarcely addressed in the existing literature for time series data of an individual country are the heterogeneity of the health expenditure, role of technology, effect of structural break and dynamic nature of health expenditure. Accordingly, heterogeneity in health expenditure implies different patterns of behavior among the components of total government health expenditure Clemente, et al. (2004) and Sharma and Srivastava (2011). To address the issue of heterogeneity we have considered three versions of health expenditure namely Total Health Expenditure (THE), Development Health Expenditure (DHE) and Recurring Health Expenditure (RHE). For each component we have specified models for estimation of income elasticity considering the government expenditure on health (represented by $G$ ) as dependent variableand income (represented by GDP) as independent variable. These specifications in each case are discussed below along with the underlying assumptions. For the purpose of estimating income elasticity, GDP is the main regressor. In model 1 our assumption is that the health care expenditure is influenced by the current GDP and hence the model is static.

$$
\text { Model 1: } \log \mathrm{G}_{\mathrm{t}}=\alpha+\eta \log \mathrm{GDP}_{\mathrm{t}}+\mathrm{u}_{\mathrm{t}}
$$


Table 3. ARC- elasticity of private expenditures on medical carehouseholds data

\begin{tabular}{|l|l|c|c|c|c|}
\hline \multirow{2}{*}{ Author (Period) } & \multirow{2}{*}{$\begin{array}{l}\text { Expenditure } \\
\text { on Medical } \\
\end{array}$} & \multicolumn{4}{|c|}{ Income Elasticity Estimates } \\
\cline { 3 - 6 } & Total & Urban & $\begin{array}{l}\text { Urban / } \\
\text { Village }\end{array}$ & Rural \\
\hline $\begin{array}{l}\text { 1993/94 and } \\
\text { 2002/03* }\end{array}$ & Botswana & 0.3011 & 0.1170 & 0.6423 & 0.1689 \\
\hline $\begin{array}{l}\text { Okunade (1985) } \\
1960-1972\end{array}$ & Ghana & & 0.24 & & 0.25 \\
\cline { 2 - 6 } & Kenya & & 1.58 & 1.33 & 1.25 \\
\cline { 2 - 6 } & Malawi & & 0.61 & & 0.51 \\
\cline { 2 - 6 } & Sudan & & 0.83 & 0.72 & 0.85 \\
\cline { 2 - 6 } & Tanzania & 0.34 & 1.70 & & \\
\hline
\end{tabular}

Source: Authors' elaboration. * using Households Income Expenditure Survey (HIES) data.

Second issue is the role of technology in health care (Pratt, 2015). The income elasticity estimated will be biased upward if technology effect is not controlled. Following Blomqvist and Carter (1997), Ariste and Carr (2003), Woodward and Wang (2012) and Di Matteo and Di Matteo (1998), we extend the model (1) by a linear and deterministic time trend (TIME) to account for the impact of endogenous technological change on health care expenditure in the model which becomes

$$
\text { Model 2: } \log \mathrm{G}_{\mathrm{t}}=\alpha+\eta \log \mathrm{GDP}_{\mathrm{t}}+\beta(\mathrm{TIME})+\mathrm{u}_{\mathrm{t}}
$$

Third issue is the effect of structural break on the income elasticity of health expenditure. Introduction of the MASA programme in 2002 is considered as structural break and dummy (MASA) has been introduced which takes the value zero during 1981-2001 and one during the period 2002-2016. The equilibrium relationship is considered as below:

$$
\text { Model 3: } \log \mathrm{G}_{t}=\alpha+\eta \log \mathrm{GDP}_{\mathrm{t}}+\beta(\text { MASA })+\mathrm{u}_{\mathrm{t}}
$$

Fourth issue in the analysis of the health expenditure is the dynamic aspects. Most of the earlier studies have estimated static model, but the change in income do not influence the health expenditure immediately (Roberts, 1999; Lago-Penas, et al., 2013). As discussed earlier we have estimated a dynamic model underlying assumption is that the healthcare expenditures do not adapt to changes in per capita GDP immediately. Lagged expenditure is included as an additional relevant to explain current expenditure so that short-run and long-run income elasticity's may be estimated separately. Following Phillips and Loretan (1991) and Lago-Peñas, et al., (2013), we have employed ARDL $(1,0)$ model as an alternative to model 1 for the estimation of the long run income elasticity

$$
\text { Model 4: } \log \mathrm{G}_{\mathrm{t}}=\alpha+\eta \log \mathrm{GDP}_{\mathrm{t}}+\beta \log \mathrm{G}_{\mathrm{t}-1}+\mathrm{u}_{\mathrm{t}}
$$

The short-run elasticity of income on health care expenditure $\underline{i} \underline{\eta} \eta$ whereas the long run elasticity is given by $\eta /(1-\beta)$ (Lago-Penas, et al., 2013).

Available evidence on growth of health expenditure has indicated that possibility of misspecification while estimating income elasticity of expenditure might be responsible for wide variation in its magnitude (Barros, 1998; Culyer, 1988; Di Matteo \& Di Matteo, 1998; Hansen \& King, 1996). We have employed the Ramsey's RESET (Regression equation specification error test) test for model misspecification; or rather a missing variable(s) in each case for testing the null hypothesis of no misspecification to avoid omitted variable bias (Lothgren \& Gerdtham, 2002; Pratt, 2015).

\subsection{Empirical Analysis}

Taking aforesaid facts into account, we have considered the data for 1981-2016 for Botswana in estimating the income elasticity of three definitions of health expenditures namely total, recurring and development expenditure. Choice of period is dictated by the fact that first case of HIV in Botswana was in 1984. Following Peters, et al., (1999) and Sharma and Srivastava (2011), we have considered total government expenditure on health disaggregated into two categories namely development and recurring expenditure for the period 1981-2016. All the variables are logged and have been considered at current price because use of GDP deflator is always questionable (Narayan, et al., 2011). The data are obtained from the Annual Report of Bank of Botswana. The summary statistics of the variables in level is presented in (Table 4).

\subsection{Econometric Analysis of the Government Expenditure on Health}

The results are given in Table 5 present the estimates of regression model. For the purpose of estimating 
Table 4. Summary statistics, using the observations 1981- 2016

\begin{tabular}{|l|c|c|c|c|}
\hline & DHE & RHE & THE & GDP \\
\hline Mean & 341.8922 & 1262.142 & 1586.637 & 43233.76 \\
\hline Median & 103.1950 & 361.6050 & 505.4800 & 23365.65 \\
\hline Maximum & 1350.800 & 5902.000 & 6325.000 & 169688.0 \\
\hline Minimum & 4.190000 & 12.23000 & 17.75000 & 780.1000 \\
\hline Std. Dev. & 429.9503 & 1777.296 & 1933.913 & 47889.43 \\
\hline Skewness & 1.058555 & 1.542388 & 1.090522 & 1.207867 \\
\hline Kurtosis & 2.540402 & 4.068139 & 2.908882 & 3.322850 \\
\hline Jarque-Bera & 7.040078 & 15.98515 & 7.147886 & 8.910003 \\
\hline P-value & 0.029598 & 0.000338 & 0.028045 & 0.011620 \\
\hline Sum & 12308.12 & 45437.12 & 57118.94 & 1556415. \\
\hline Sum Sq. Dev. & 6470004. & $1.11 \mathrm{E}+08$ & $1.31 \mathrm{E}+08$ & $8.03 \mathrm{E}+10$ \\
\hline Observations & 36 & 36 & 36 & 36 \\
\hline
\end{tabular}

income elasticity variables have been considered in a log-linear model (column 3). As discussed earlier, to examine the robustness of the estimates we have adopted four specifications of the model. First we have estimated simple static regression model with health expenditure as the dependent variable using ordinary least square method. Goodness of fit is very high in all cases. The income elasticity has been estimated for total government health expenditures (THE) on health and its two subcomponents namely Development Health Expenditure (DHE) and Recurring Health Expenditure (RHE). The income elasticity is positive and above unity, it is 1.05 in case of development expenditure and 1.22 in case of recurring and total expenditure. The

Source: Author's elaboration.

Table 5. Estimating regression model elasticity estimates-1981-2016

\begin{tabular}{|c|c|c|c|c|c|c|c|}
\hline Govt. Exp. $(\log Y)_{t}$ & Intercept & $\log \mathrm{GDP}_{\mathrm{t}}$ & MASA & TIME & $\log Y_{t-1}$ & Adj. R² DW & $\begin{array}{l}\text { RESET Test } \mathrm{H}_{0} \text { : No Mis- } \\
\text { specifi-cation }\end{array}$ \\
\hline (1) & (2) & (3) & (4) & (5) & (6) & (7) & (8) \\
\hline \multirow[t]{4}{*}{$\begin{array}{l}\text { Total Health Expenditure } \\
\text { (THE) }\end{array}$} & $\begin{array}{l}-6.0472 \\
(0.0000)\end{array}$ & $\begin{array}{l}1.2384^{\star \star \star} \\
(0.0000)\end{array}$ & & & & 0.97840 .5019 & Rejected \\
\hline & $\begin{array}{l}-4.4373 \\
(0.0000)\end{array}$ & $\begin{array}{c}1.0439^{\star \star \star} \\
(0.0000)\end{array}$ & $\begin{array}{l}0.7382 \\
(0.0000)\end{array}$ & & & 0.99320 .9136 & Not Rejected \\
\hline & $\begin{array}{l}-1.0262 \\
(0.2516)\end{array}$ & $\begin{array}{l}0.5383 \\
(0.0000)\end{array}$ & & $\begin{array}{l}0.1017 \\
(0.0000)\end{array}$ & & 0.98980 .4288 & Rejected \\
\hline & $\begin{array}{l}-0.7067 \\
(0.4235)\end{array}$ & $\begin{array}{c}0.2200 \\
(0.0447)\end{array}$ & & & $\begin{array}{l}0.8126 \\
(0.0000)\end{array}$ & $0.99561 .468^{*}$ & Not Rejected \\
\hline \multirow[t]{4}{*}{$\begin{array}{l}\text { Recurring Health } \\
\text { Expenditure (RHE) }\end{array}$} & $\begin{array}{l}-6.6319 \\
(0.0000)\end{array}$ & $\begin{array}{l}1.2634^{\star \star \star} \\
(0.0000)\end{array}$ & & & & 0.97760 .6794 & Rejected \\
\hline & $\begin{array}{l}-5.5554 \\
(0.0000)\end{array}$ & $\begin{array}{l}1.1333^{\star * \star} \\
(0.0000)\end{array}$ & $\begin{array}{l}0.4936 \\
(0.0013)\end{array}$ & & & 0.98370 .7486 & Rejected \\
\hline & $\begin{array}{c}0.0263 \\
(0.9693)\end{array}$ & $\begin{array}{c}0.3350 \\
(0.0039)\end{array}$ & & $\begin{array}{c}0.1349 \\
(0.0000)\end{array}$ & & 0.99570 .9364 & Rejected \\
\hline & $\begin{array}{l}-0.7853 \\
(0.1030)\end{array}$ & $\begin{array}{l}0.1840 \\
(0.0316)\end{array}$ & & & $\begin{array}{c}0.8485 \\
(0.0000)\end{array}$ & $0.99722 .7043^{*}$ & Not Rejected \\
\hline \multirow[t]{4}{*}{$\begin{array}{l}\text { Development Health } \\
\text { Expenditure (DHE) }\end{array}$} & $\begin{array}{l}-5.7348 \\
(0.0000)\end{array}$ & $\begin{array}{l}1.0565^{\star \star} \\
(0.0000)\end{array}$ & & & & 0.79660 .5359 & Not Rejected \\
\hline & $\begin{array}{l}-3.0247 \\
(0.0142)\end{array}$ & $\begin{array}{c}0.7291 \\
(0.0000)\end{array}$ & $\begin{array}{l}1.2428 \\
(0.0034)\end{array}$ & & & 0.84960 .6197 & Rejected \\
\hline & $\begin{array}{l}-7.0299 \\
(0.0607)\end{array}$ & $\begin{array}{l}1.2371^{\star *} \\
(0.0180)\end{array}$ & & $\begin{array}{l}-0.0262 \\
(0.7142)\end{array}$ & & 0.80490 .5414 & Not Rejected \\
\hline & $\begin{array}{l}-1.2748 \\
(0.1614)\end{array}$ & $\begin{array}{c}0.2735 \\
(0.0474)\end{array}$ & & & $\begin{array}{c}0.7162 \\
(0.0000)\end{array}$ & $0.89511 .9583^{\star}$ & Not Rejected \\
\hline
\end{tabular}

Source: Author's calculations: Figures in parentheses are the $p$-values.

*DW not valid, $\mathrm{H}_{0}$ : Income elasticity that is the coefficient of $\mathrm{Y}_{\mathrm{t}}=1 .{ }^{* \star} \mathrm{H}_{0}$ is not rejected, ${ }^{* \star} \mathrm{H}_{0}$ Rejected 
null hypothesis of unit income elasticity is tested in cases where the estimated coefficient of income is one or above. However, the null hypothesis of unitary longrun elasticity is rejected at $95 \%$ level of confidence considering one side test. Available evidence suggests that the GDP alone explains more than $75 \%$ in health expenditure.

In the second model, a dummy variable is considered for one structural break in the government expenditure on health due to MASA programme (column 4). However it does not alter the size of the income elasticity for total expenditure and recurring expenditure, but its effect as structural break is significant. In ascertaining the magnitude of the elasticity of health expenditure with respect to GDP, the null hypothesis that the coefficient on $\log$ GDP is equal to one is tested and the null hypothesis is rejected in two cases namely total health expenditure and recurring health expenditure. The MASA dummy is significant in each case without altering the magnitude of the estimates of income elasticity suggesting that MASA has acted as regime shift and affected the government expenditure on health.

The third model considers the time trend (column 5) which is introduced for technical change, but the relationship between technical change and expenditure on health is ambiguous. Technical progress may reduce the cost of producing a given output; however, it also increases the effectiveness of medical interventions producing both demand and supply-side reasons for increasing expenditure. The time trend has been included to consider change in technology, quality of health care and efficiency of the health system into account. The sign of the net effect of technology is an empirical question. When we introduce time as a proxy for technology the estimate of elasticity comes down below unity in two cases namely total health expenditure and recurring expenditure and in each case the coefficient is significant. Our findings support Dybczak and Przywara (2010). However in case of development expenditure the trend variable is negative and is not significant.

Fourth model used here for estimating the income elasticity of health expenditure has the dynamic specification. Unlike most of the earlier studies which are based on contemporaneous income elasticity of health expenditure we have considered the dynamic aspects of the health expenditure. Accordingly, we have considered a dynamic specification also and the results are given in column 6 in (Table 5). The coefficient of lag dependent variable is significant in all the three cases. According to econometric estimates, the estimated short-run elasticity is less than 0.3 , but the long-run elasticity is greater than one for total and recurring expenditure. However, the hypothesis of long run unitary elasticity is rejected in both cases. For development expenditure it is 0.98 less than one. Our results are comparable with Lago-Peñas, et al., (2013).

In six cases the estimated elasticity is close to unity. In such cases we test the null hypothesis that the elasticity is equal to unity. In four cases the null hypothesis is rejected. Finally, RESET test for misspecification is conducted. Failure to reject $\mathrm{H}_{0}$ in RESET test for all the three versions of health expenditure is consistent with the model being correctly specified. Rejection of the joint hypothesis is an indication of misspecification. Applying the RESET test null hypothesis of no misspecification cannot be rejected in six out of 12 cases estimated. Our results conclude that the dynamic model is the most suitable specification for estimating income elasticity of health expenditure. The null of no misspecification is not rejected therefore the base model is consistent in the functional form only for the development expenditure.

\section{Summary and Conclusion}

Botswana ranked second among the 13 SADC countries in terms of total health expenditure per capita. Comparing with other middle income countries, Botswana has lower health outcome. If the income elasticity for Botswana is greater than one then health may be considered as luxury and health care would be left to private sector. Studies based on the micro level data have estimated income elasticity with smaller magnitude suggesting that the health is a necessity. One of the issues, which have discussed in most of the studies considering analysis of health care expenditure, is whether health care is a luxury 
or a necessary good. This issue is intriguing due to the potential implications for redistribution. At the aggregate level across the countries, the estimates of income elasticity often exceed unity and it declines as the unit of observation moves towards disaggregation. Several attempts have been made to estimate income elasticity of health expenditure for developed countries or group of developed countries such as OECD. Wide variation in the size of income elasticity and sometimes contradictory results are observed. The evidence found in most studies suggests a strong positive relationship between health care expenditure and gross domestic product with income elasticity greater than unity at the aggregate level.

In the present study an attempt is made to estimate the income elasticity for Botswana - a country which is commended for meeting the Abuja targets but with adverse health outcome. Our conclusions for Botswana support that health is a necessity both at the micro or macro level. In developed and upper middle income courtiers the income elasticity at the aggregate level is greater than unity because of larger spending on newer technological improvements which is always more expensive in the beginning. Botswana being an upper middle income country, this evidence weakens with respect to the actual value of the income elasticity when micro level data are considered. There are two possible sources for this discrepancy, first the measurement error and the second the specification error. The problem is that the components of health expenditure at the aggregate level do not move together. There exists a strong positive relationship between health care expenditure and GDP. However short run income elasticity is below unity. The magnitude of income elasticity is more or less the same regardless of nature of health care expenditure. Our results confirm the importance of non-income variables, such as technology having a strong rationing effect on the quantity of health demanded, and not supporting the argument that public expenditure on health is a luxury in Botswana.

\section{References}

Ariste, R., and Carr, J. (2003). New Considerations on the Empirical Analysis of Health Expenditures in Canada:
1966 - 1998. Government of Canada, Health Canada, Working Paper No. 02-06; p. 41. https://papers.ssrn. com/sol3/papers.cfm?abstract_id=1015789.

Baltagi, B. H. and Moscone, F. (2010). Health care expenditure and income in the OECD reconsidered: Evidence from panel data, Economic Modelling. 27(4):804-811. https://doi.org/10.1016/j.econmod.2009.12.001.

Barros, P. P. (1998). The black box of health care expenditure growth determinants, Health Econ. 7(6):533-544. https://doi.org/10.1002/(SICI)10991050(199809)7:6<533::AID-HEC374>3.0.CO;2-B.

Blomvist, A. G. and Carter, R. A. (1997). Is health care really a luxury? Journal of Health Economics. 16:207229. https://doi.org/10.1016/S0167-6296(96)00534-6.

Boungarasy, M. (2011). Health care expenditures in Asia countries: Panel data analysis, Economics Bulletin. 31(4):3169-3178.

Blomqvist, A. G., \& Carter, R. A. (1997). Is health care really a luxury?. Journal of health economics, 16(2), 207-229.

Carrion-i-Silvestre, J. L. (2005). Health care expenditure and GDP: Are they broken stationary? Journal of Health Economics. 24:839-854. https://doi.org/10.1016/j. jhealeco.2005.01.001. PMid: 16129126.

Chakroun, M. (2010). Health care expenditure and GDP: An International panel smooth transition approach, International Journal of Economics. 4(1):189-200.

Clemente, J., Marcuello, C., Montanes, A. and Pueyo, F. (2004). On the International stability of health care expenditure functions: Are government and private functions similar? Journal of Health Economics. 23:589-613. https://doi.org/10.1016/j.jhealeco.2003.08.007. PMid: 15120472.

CSO. (2004). Household Income and Expenditure Survey 2002/03, Main Report, Volume 1. Gaborone: Central Statistics Office, Republic of Botswana, Department of Printing and Publishing Services, Gaborone; p. 188. http:/www.statsbots.org.bw/sites/default/files/ Household\%20Income\%20And $\% 20$ Expenditure $\% 20$ Survey\%202002.pdf.

Culyer, T. (1988). Health Care Expenditures in Canada: Myth and Reality; Past and Future. Canadian Tax Foundation, Toronto; p. 110. https://pure.york.ac.uk/portal/en/ publications/health-care-expenditures-in-canada-mythand-reality-past-and-future(8b336a5e-769a-47d99c28-51b1c1255088).html.

Culyer, A. J. (1989). Cost Containment in Europe, Health Care Financing Review. 11(1):21-32. https://www.ncbi. nlm.nih.gov/pmc/articles/PMC4195143/.

Di Matteo, L. and Di Matteo, R. (1998). Evidence on the determinants of Canadian provincial government 
health expenditures: 1965-1991, Journal of Health Economics. 17(2):211-228. https://doi.org/10.1016/ S0167-6296(97)00020-9.

Dregen, C. and Reimers, H. E. (2005). Health care expenditures in OECD countries: A panel unit root and cointegration analysis, International Journal of Applied Econometrics and Quantitative Studies. 2:5-20.

Dybczak, K. and Przywara, B. (2010). The role of technology in health care expenditure in the EU, Economic Papers 400. Economic and Financial Affairs, European Economy; p. 26. https://ec.europa.eu/info/ business-economy-euro/economy-finance-and-europublications_en.

Freeman, D. G. (2003). Is health care a necessity or a luxury? Pooled estimates of income elasticity from US state-level data, Applied Economics. 35(5):495-502. https://doi.org/10.1080/00036840210138374.

Fuchs, V. R. and Kramer, M. J. (1973). Determinants of expenditure for Physicians services in the United States, 1948-1968, Occasional Paper No.117. NY: NBER; p. 72. ISBN: 0-87014-247-X. https://www.nber.org/ books/fuch73-1.

Gerdtham, U. G. and Jonsson, B. (1991). Price and quantity in international comparisons of health expenditure, Applied Economics. 23:1519-1528. https://doi. org/10.1080/00036849100000204.

Gerdtham, U. G., Sogaard, F., Anderson, F. and Jonsson, B. (1992). An econometric analysis of health care expenditures: A cross-section study of the OECD countries, Journal of Health Economics. 11:63-84. https://doi. org/10.1016/0167-6296(92)90025-V.

Getzen, T. E. (2000). Health Care is an individual necessity and a nation luxury, Journal of Health Economics. 19:259-70. https://doi.org/10.1016/S01676296(99)00032-6.

Grossman, M. (1972). On the concept of health capital and the demand for health. Journal of Political economy, 80(2), 223-255.

Goodman, A. C. (2000). New Estimates of Cross-National Health Expenditures. Detroit, Michigan: Wayne State University. http://www.econ.wayne.edu/agoodman/ research/PUBS/New_Estimates.pdf.

Hansen, P. and King, A. (1996). The derminnants of health care expenditure: A cointegration approach, Journal of Health Economics. 15:127-137. https://doi. org/10.1016/0167-6296(95)00017-8.

Hitiris, T. (1997). Health care expenditure and integration in the countries of the European Union, Appl. Econ. 29(1):1-6. https://doi.org/10.1080/000368497327335.
Hitiris, T. and Posnett, J. (1992). The determinants and effects of health expenditure in developed countries, Journal of Health Economics. 173-181. https://doi. org/10.1016/0167-6296(92)90033-W.

Istaiteyeh, R. M. and Ismail, M. T. (2017). Stationarity and cointegration between health care expenditure and GDP for Jordan, American Journal of Applied Sciences. 14(7):682-689. https://doi.org/10.3844/ ajassp.2017.682.689

Jaunky, V. C. and Khandaroo, A. J. (2008). Health care expenditure and GDP: An African perspective, Econometrics and International Development. 8:131-146.

Khan, H. N., Khan, M. A., Razdi, R. B., Sahfie, A. B., Shehzada, G., Krebs, K. L., et al. (2016). Health care expenditure and economic growth in SAARC countries (1995-2012): A panel causality analysis, Applied Research Quality Life. 11:639-661. https://doi. org/10.1007/s11482-015-9385-z.

Kiymaz, H., Akbulut, Y. and Demir, A. (2006). Tests of stationarity and cointegration of health care expenditure and gross domestic product: An application to Turkey, The European Journal of Health Economics. 7(4):285289. https://doi.org/10.1007/s10198-006-0375-9. PMid: 17109146.

Lago-Penas, S., Cantarero-Prieto, D. and BlazquezFernandez, C. (2013). On the relationship between GDP and health care expenditure: A new look, Economic Modelling. 32:124-129..https://doi.org/10.1016/j.econ$\bmod$ 2013.01.021.

Leu, R. E. (1986). The public-private mix and international health care cost. In: A. J. Culyer, \& B. Jonsson, Public and Private Health Services, B. Blackwell; p. 41-63.

Liu, D., Li, R. and Wang, Z. (2011). Testing for structural breaks in panel varying coefficient models: with an application to OECD health expenditure, Empir. Econ. 40:95-118. https://doi.org/10.1007/s00181-010-0375-6.

Lothgren, M. and Gerdtham, U. (2002). New panel results on cointegration of international health expenditures and GDP. Applied Economics, 34:1679-1686. https:// doi.org/10.1080/00036840110116397.

Lule, E. and Haacker, M. (2012). Fiscal Dimension of HIV/AIDS in Botswana, South Africa, Swaziland, and Uganda. Washington D.C.: World Bank. https://doi. org/10.1596/978-0-8213-8807-5.

Moscone, F. and Tosetti, E. (2010). Health expenditure and income in the United States, Health Economics. 19:1385-1403. https://doi.org/10.1002/hec.1552. PMid: 19842092. 
Murillo, C., Piatecki, C. and Saez, M. (1993). Health care expenditure and income in Europe. Health Economics. 2:127-138. https://doi.org/10.1002/hec.4730020206. PMid: 8261034.

Murthy, V. N. and Okunade, A. A. (2009). The core determinants of health expenditure in the African context: Some econometric evidence for policy, Health Policy. 91(1):57-62. https://doi.org/10.1016/j.healthpol.2008.10.001. PMid: 19108929.

Narayan, P. K., Narayan, S. and Smyth, R. (2011). Is health care really a luxury in OECD countries? Evidence from Alternative Price Deflators, Applied Economics. 43:3631-3643. https://doi. org/10.1080/00036841003670788.

Newhouse, J. P. (1977). Medical-care expenditures: A crossnational survey, Journal of Human Resources. 12:112-25. https://doi.org/10.2307/145602. PMid: 404354.

Okunade, A. A. (2005). Analysis and implications of the determinants of healthcare expenditure in African countries, Health Care Manag. Science. 8(4):267-76. https://doi.org/10.1007/s10729-005-4137-5. PMid: 16379410.

Okunade, A. A (1985). Engel curves for developing nations: The case of Africa, Eastern Africa Economic Review. 11(1):13-22.

Okunade, A. A. and Murthy, V. N. (2002). Technology as a major driver of health care costs: A cointegration analysis of the newhouse conjecture, Journal of Health Economics. 21:147-159. https://doi.org/10.1016/ S0167-6296(01)00122-9.

Onyatseng, G., \& Sinha, N. (2013). The nursing labour market in Botswana: An economic analysis.

Parker, S. and Wong, R. (1997). Household income and health care expenditures in Mexico, Health Policy. 40:237255. https://doi.org/10.1016/S0168-8510(97)00011-0.

Parkin, D., McGuire, A. and Brian, Y. (1987). Aggregate health care expenditures and national income: Is health is a luxury good? Journal of Health Economics. 6:109127. https://doi.org/10.1016/0167-6296(87)90002-6.

Peters, D. H., Kandola, K., Elmendorf, A. E. and Chellaraj, G. (1999). Health Expenditures, Services and Outcomes in Africa-Basic Data and Cross national Comparisons, 1990-1996. Washington, DC: The World Bank. https:// doi.org/10.1596/0-8213-4438-2.

Phelps, C. E. (2003). Health Economics. New York: Harper Collins. ISBN-13: 978-0321068989.

Phillips, P. C. and Loretan, M. (1991). Estimating long run economic equilibria, Review of Economic Studies. 5:407-436. https://doi.org/10.2307/2298004.
Piabuo, S. M. and Tieguhong, J. C. (2017). Health expenditure and economic growth $-\mathrm{A}$ review of the literature and an analysis between the economic community for central African states (CEMAC) and selected African countries, Health Economics Review. 7(1):1-13. https:// doi.org/10.1186/s13561-017-0159-1. PMid: 28593509, PMCid: PMC5462666.

Pratt, W. R. (2015). Health care expenditures in OECD countries, identifying the cost of technology, Journal of Accounting and Finance. 15(6):66-84.

Republic of Botswana (2012). Botswana National Health Accounts for Financial Years. Gaborone: Ministry of Health, Gaborone.

Rezaei, S., Fallah, R., Karyani, A. K., Daroudi, R., Zandya, H., Zandiyan, H., et al. (2016). Determinants of healthcare expenditures in Iran: Evidence from a time series analysis, Medical Journal of the Islamic Republic of Iran (MJIRI). 30(313):1-9.

Roberts, J. (1999). Sensitivity of elasticity estimates for OECD health care spending: Analysis of a dynamic heterogeneous data field, Health Economics. 8(5):459-472. https://doi.org/10.1002/(SICI)10991050(199908)8:5<459::AID-HEC454>3.0.CO;2-U.

Roberts, J. (2000). Spurious regression problems in the determinants of health care expenditure: A comment on Hitiris (1997), Applied Economics Letters. 7(5):279283. https://doi.org/10.1080/135048500351393.

Saez, M. and Murillo, F. C. (1994). Shared 'features' in prices: Income and price elasticities for health care expenditures, Health Economics. 3(4):267-279. https:// doi.org/10.1002/hec.4730030408. PMid: 7994326.

Schieber, G. J. (1992). Health care expenditure in major industrialized countries, 1960-1987, Health Care Financing Review. 11:159-167.

Sen, A. (2005). Is health care a luxury? New evidence from OECD data, International Journal of Health Care Finance and Economics. 5(2):147-164. https://doi. org/10.1007/s10754-005-1866-4. PMid: 15912314.

Sharma, A. and Srivastava, P. (2011). Does disaggregation affect the relationship between health care expenditure and GDP? An analysis using regime shifts, Australian Economic Papers. 50(1):27-39. https://doi.org/10.1111/ j.1467-8454.2011.00409.x.

Silver, M. (1970). An Economic Analysis of Variations in Medical Expenses and Work-Loss Rates. In: H. E. Klarman (Ed.), Empirical Studies in Health Economics. Baltimore, MD: John Hopkins University Press.

Smith, S., Newhouse, J. and Freefand, M. (2009). Income, insurance and technology: Why does health spending 
outpace economic growth? Health Affairs. 1276-1284. https://doi.org/10.1377/hlthaff.28.5.1276. $\quad$ PMid: 19738242.

Sulku, S. and Caner, A. (2011). Health care expenditures and gross domestic product: The Turkish case, Journal of Health Economics. 12(1):29-38. https://doi. org/10.1007/s10198-010-0221-y. PMid: 20151170.

WHO. (2005). Botswana, Summary Country Profile for HIV/AIDS Treatment Scale-Up. Geneva: World Health Organization.
WHO. (2013). Research for Universal Health Coverage. The World Health Report 2013. Geneva: World Health Organization.

WHO. (2016). Public Financing for Health in Africa: From Abuja to the SDGs. Geneva: World Health Organization. Woodward, R. S. and Wang, L. (2012). The oh-so straight and narrow path: Can the health care expenditure curve be bent? Health Economics. 21(8):1023-1029. https:// doi.org/10.1002/hec.1765. PMid: 21755571. 
Appendix: Table Dependent variable: national health care expenditure.

\begin{tabular}{|c|c|c|c|}
\hline Authors & Sample Model description & Sample & Income Elasticity \\
\hline Newhouse (1977) & 13 developed countries & Cross section & $>1$ \\
\hline Leu (1986) & 19 OECD countries & Cross section & $>1$ \\
\hline Parkin, et al. (1987) & 18 OECD countries & Cross section & $>1$ \\
\hline Hitiris and Posnett (1992) & 20 OECD countries & Panel data. & close to unity \\
\hline Gerdtham, et al. (1992) & OECD countries & Panel data & \\
\hline Hansen and King (1996) & 20 OECD countries & Time series & No long run relation \\
\hline Blomquist and Carter(1997) & 24 Developed countries & Panel data & \\
\hline Hitiris (1997) & 10 OECD countries & Time series & $>1$ \\
\hline Schieber (1992) & Industrialized countries & Panel data & $>1$ \\
\hline Freeman (2003) & US States & Panel data & $<1$ \\
\hline Sen (2005) & 15 OECD countries & Panel data & $<1$ \\
\hline Dregerd and Reimers (2005) & 21 OECD countries & Panel cointegration & $<1$ \\
\hline Smith, et al. (2009) & & & $>1$ \\
\hline Murthy and Okunade (2009) & 44 African countries & & $<1$ \\
\hline Jaunky and Khandaroo (2008) & African countries & & $<1$ \\
\hline Chakroun (2010) & 17 OECD countries & $\begin{array}{l}\text { Multivariate } \\
\text { regression }\end{array}$ & $<1$ \\
\hline Moscone and Tosetti, (2010) & US States & & $<1$ \\
\hline Mehrara, et al. (2010) & 16 OECD countries & Panel data & $>1$ \\
\hline Baltagi and Moscone (2010) & 20 OECD countries & Panel data & $<1$ \\
\hline Liu, et al. (2011) & 22 OECD countries & Panel varying coeff & $>1$ \\
\hline Narayan, et al. (2011) & OECD countries & Panel data & $>1$ \\
\hline Woodward and Wang (2012) & US states & Panel data & $1.388>1$ \\
\hline \multirow[t]{3}{*}{ Silver (1970) } & All Expenditure & & 1.2 \\
\hline & Physician expenses & & 0.85 \\
\hline & Dental Care- Expenditures & & 2.14 to $3.20>1$ \\
\hline Rosett and Huang (1973) & All Expenditure & & 0.25 to 0.45 \\
\hline Okunade (2005) & Health Expenditure(per cap) & Africa Panel & 0.60 \\
\hline \multirow[t]{2}{*}{ Newhouse and Phelps (1976) } & Hospital Services & & 0.02 to 0.04 \\
\hline & Expenditure-Visits & & 0.01 to 0.04 \\
\hline Anderson and Benham (1970) & $\begin{array}{c}\text { Physician care - } \\
\text { Expenditure Dental Services }\end{array}$ & & $\begin{array}{l}0.85 \\
0.40\end{array}$ \\
\hline Fuchs and Kramer (1973) & $\begin{array}{c}\text { Expenditure per capita } \\
\text {-Visits }\end{array}$ & & 0.20 to 0.57 \\
\hline Feldstein (1971) & Dental expenses & & 0.5 \\
\hline Chiswick (1976) & Nursing Homes & & 0.60 to 0.90 \\
\hline Parker and Wong (1997) & Mexico (All expenses) & & $0.9-1.6$ \\
\hline Freeman (2003) & Health Care Expenditure & & 0.82 to 0.84 \\
\hline
\end{tabular}

Source: Authors' elaboration 


\section{Appendix: DATA}

Table A1. Private Exp. on Health Care and Disposable Income Botswana

\begin{tabular}{|l|c|c|c|c|c|}
\hline Variable & Year & Total & Urban & U/V & Rural \\
\hline \multirow{2}{*}{$\begin{array}{l}\text { Expenditure (in } \\
\text { Pula) }\end{array}$} & $2003 / 04$ & 39.50 & 63.50 & 50.40 & 15.30 \\
\cline { 2 - 6 } & $1993 / 94$ & 28.01 & 55.09 & 23.62 & 12.89 \\
\hline $\begin{array}{l}\text { Disposable Income } \\
\text { (in Pula) }\end{array}$ & $2003 / 04$ & 2424.6 & 3961.1 & 2445.5 & 1378.90 \\
\cline { 2 - 6 } & $1993 / 94$ & 1026.4 & 1718.8 & 884.40 & 654.40 \\
\hline
\end{tabular}

Basic Source: HIES, 2003-04 and 1993-94

Table A2. GDP and Government Expenditures on Health (in Million Pula), Botswana

\begin{tabular}{|c|c|c|c|c|c|c|c|}
\hline \multirow{2}{*}{ Year } & \multicolumn{3}{|c|}{ Government Expenditure on Health } & \multirow{2}{*}{$\begin{array}{l}\text { GDP Current } \\
\text { Price }\end{array}$} & \multicolumn{2}{|c|}{ Share in Total Expenditure on Health } & \multirow{2}{*}{ THE/ GDP (\% } \\
\hline & Recurring (RHE) & Development (DHE) & Total (THE) & & Rec. Exp. (\%) & Dev. Exp. (\%) & \\
\hline 1981 & 12.23 & 5.52 & 17.75 & 780.10 & 68.90 & 31.10 & 2.28 \\
\hline 1982 & 14.12 & 4.19 & 18.31 & 1029.00 & 77.12 & 22.88 & 1.78 \\
\hline 1983 & 16.37 & 6.23 & 22.60 & 1390.90 & 72.43 & 27.57 & 1.62 \\
\hline 1984 & 20.17 & 4.97 & 25.14 & 1828.60 & 80.23 & 19.77 & 1.37 \\
\hline 1985 & 22.46 & 9.49 & 31.95 & 2420.60 & 70.30 & 29.70 & 1.32 \\
\hline 1986 & 31.04 & 22.52 & 53.56 & 2809.80 & 57.95 & 42.05 & 1.91 \\
\hline 1987 & 38.39 & 48.62 & 87.01 & 6914.60 & 44.12 & 55.88 & 1.26 \\
\hline 1988 & 48.72 & 31.32 & 80.04 & 5836.80 & 60.87 & 39.13 & 1.37 \\
\hline 1989 & 57.33 & 31.30 & 88.63 & 6539.70 & 64.68 & 35.32 & 1.36 \\
\hline 1990 & 82.76 & 36.96 & 119.72 & 7565.00 & 69.13 & 30.87 & 1.58 \\
\hline 1991 & 94.44 & 32.89 & 127.33 & 8376.50 & 74.17 & 25.83 & 1.52 \\
\hline 1992 & 123.15 & 35.17 & 158.32 & 9119.20 & 77.79 & 22.21 & 1.74 \\
\hline 1993 & 162.78 & 38.73 & 201.51 & 11041.40 & 80.78 & 19.22 & 1.83 \\
\hline 1994 & 183.98 & 43.51 & 227.49 & 12261.70 & 80.87 & 19.13 & 1.86 \\
\hline 1995 & 225.30 & 31.33 & 256.63 & 14203.90 & 87.79 & 12.21 & 1.81 \\
\hline 1996 & 241.61 & 57.57 & 299.18 & 17740.20 & 80.76 & 19.24 & 1.69 \\
\hline 1997 & 301.58 & 109.62 & 411.20 & 20162.60 & 73.34 & 26.66 & 2.04 \\
\hline 1998 & 372.98 & 95.38 & 468.36 & 21523.70 & 79.64 & 20.36 & 2.18 \\
\hline 1999 & 350.23 & 192.37 & 542.60 & 25207.60 & 64.55 & 35.45 & 2.15 \\
\hline 2000 & 533.10 & 96.77 & 629.87 & 28636.50 & 84.64 & 15.36 & 2.20 \\
\hline 2001 & 673.27 & 129.72 & 802.99 & 31922.00 & 83.85 & 16.15 & 2.52 \\
\hline 2002 & 775.57 & 355.21 & 1130.78 & 26337.00 & 68.59 & 31.41 & 4.29 \\
\hline 2003 & 826.20 & 808.20 & 1634.40 & 37182.00 & 50.55 & 49.45 & 4.40 \\
\hline 2004 & 1018.90 & 1057.10 & 2076.00 & 42037.00 & 49.08 & 50.92 & 4.94 \\
\hline 2005 & 959.70 & 1096.80 & 2056.40 & 50752.00 & 46.67 & 53.34 & 4.05 \\
\hline 2006 & 1302.60 & 924.10 & 2226.60 & 59107.00 & 58.50 & 41.50 & 3.77 \\
\hline 2007 & 1512.10 & 1127.00 & 2639.10 & 67153.00 & 57.30 & 42.70 & 3.93 \\
\hline 2008 & 1886.50 & 1153.30 & 3039.80 & 75867.00 & 62.06 & 37.94 & 4.01 \\
\hline 2009 & 2021.30 & 1350.80 & 3372.10 & 72316.00 & 59.94 & 40.06 & 4.66 \\
\hline 2010 & 2475.50 & 842.50 & 3384.00 & 93390.00 & 73.15 & 24.90 & 3.62 \\
\hline 2011 & 3455.20 & 926.00 & 4381.10 & 104573.00 & 78.87 & 21.14 & 4.19 \\
\hline 2012 & 4152.60 & 202.50 & 4355.10 & 110763.00 & 95.35 & 4.65 & 3.93 \\
\hline 2013 & 4508.70 & 330.10 & 4531.10 & 124223.00 & 99.51 & 7.29 & 3.65 \\
\hline 2014 & 5291.60 & 401.60 & 5312.40 & 141942.00 & 99.61 & 7.56 & 3.74 \\
\hline 2015 & 5902.70 & 114.00 & 6012.60 & 145923.00 & 98.17 & 1.90 & 4.12 \\
\hline 2016 & 5772.10 & 553.30 & 6325.40 & 169688.00 & 91.25 & 8.75 & 3.73 \\
\hline
\end{tabular}

Source: Various Issues of Annual Reports, Bank of Botswana, Gaborone (Botswana). 